\title{
Family, Households and Women's Empowerment in Bahia, Brazil, Through the Generations: Continuities or Change?
}

\author{
Cecilia M.B. Sardenberg
}

\begin{abstract}
This article identifies changes and continuities in gender relations in a working class neighbourhood in Salvador, Bahia, through the generations. Based on data collected over a period of nearly 20 years, it seeks to identify processes of women's empowerment. It confirms the relevance of women's economic independence to their participation in decision-making and in gaining autonomy; it gave them the power to assert control over their own lives. To this end, female solidarity has also played a special role, propitiating the exercise of power with to bring about the desired changes in one's lives. However, neither economic independence nor female solidarity alone seems to have automatically led to conscious 'gender rebellion' and a break with traditional roles in the family. This only becomes possible when new values and attitudes in favour of alternative models, such as those proposed by contemporary feminisms, gain greater expression.
\end{abstract}

\begin{abstract}
1 Introduction
Those who visit Plataforma today may not realise that, in the past, it was a workers' village, home to one of the largest textile mills in Bahia. At the foot of the hill on the waterfront, the remains of the factory are now hidden away from the eyes of visitors. Until the late 1950s, first impressions of Plataforma would have been very different. Access to the neighbourhood was by train or by boat, disembarking the incoming visitors at the gates of the old factory. While conducting my doctoral research in Plataforma in the late 1980s, a newspaper article prompted me to take the train and I was able to see the community from a totally different angle. Dominating almost its entire front view, from side to side, rose Fábrica São Braz, its dirty yellowish façade framed by immense palm trees hovering upon the waterfront. Everything else - the church, the school, the roofs on the rows of little houses encrusted in the hillside - crept behind the old factory, as if they were merely outgrowths on its upward sloping backyard.
\end{abstract}

During the late 1980 s and early 1990 s, I was often in and out of Plataforma doing my research
(Sardenberg 1997a), which dealt with gender, class, and power in Bahia, based on the testimonies of former factory workers and their memories of work in the factory, their families and everyday life in the neighbourhood. Plataforma and other similar vilas operárias were not simply places for people to find employment, but also settings in which 'men and women fell in love, married, reared their children, and retired in old age' (Hall et al. 1987: 114). Housing was available so long as tenant families provided labour to the mill. But who and how many in these families should actually work in the mills, or who would share in the fruits of their labour, taking care of the other needs of the household, has depended not only on the whims and vagaries of global economies and local labour markets, but also on the composition of the households in question and on the needs, capabilities, and the preferences of their members (Parr 1990).

At Fábrica São Braz, the principles of the patriarchal family model (Borges 1992) were observed insofar as the chain of command and 
the payment of lower wages to women and youngsters were concerned (Sardenberg 1997a). In Plataforma, the 'traditional' gender divide with its ensuing distinct roles for men and women - though often transgressed and/or redefined - was the basic principle in the organisation of the family-households, as well as for the socialisation of children in the community (Sardenberg 1997a). However, by relying primarily on the employment of women and youngsters, policies at Fábrica São Braz undermined patriarchal authority in the domestic sphere. Because more women were likely to work at the mill than men, most company houses in Plataforma were rented out to women. Likewise, it was usually women who provided basic food staples acquired at the company store. In these households women assumed de facto positions as heads, particularly as men were more likely to have irregular incomes. Yet, while employment at the factory guaranteed a more regular income for women, wages were never high enough to meet household needs and therefore children had to seek employment. This contributed to the weakening of conjugal ties and to the formation of matrilocal extended households.

My original work in Plataforma had focused on the testimonies of the older generations - the people who worked in the factory - and only on a small sample of families. Would these forms of family and household organisation be true for younger families as well? During 2004 and 2005, I had the opportunity to coordinate another study in the same neighbourhood, based on a survey of 259 families headed by men and women of different age-brackets (Sardenberg and Gonçalves 2005). Since 2007, I have been coordinating a third project in the neighbourhood, in which 353 women of different generations have been interviewed (Sardenberg et al. 2008). Many of these women are members of the same family-households surveyed in the 2004-5 study, and some of them had also been part of my original research in Plataforma. Although these three studies had distinct objectives, timelines and data, it is worth drawing some comparisons, particularly insofar as change and continuities on family-household organisation and gender relations through the generations are concerned. This article seeks to do so, focusing in particular on identifying processes of women's empowerment, that is to say, the processes by which women gain autonomy and make important decisions concerning the course of their lives and of their families (Kabeer 1999).

\section{Family-household organisation and female trans-generational solidarity}

The records of the Fábrica São Braz reveal a predominant presence of women in their ranks. In 1945, women represented 85 per cent of all workers, rising to 91.2 per cent working on the production lines. The female contingent of workers in the factory was quite homogeneous: 84.5 per cent were black, 49.7 under 25, 82.8 resided in Plataforma, and 40.3 per cent were born in that neighbourhood (Sardenberg 1997b: 22-3). Successive generations of women mothers and daughters - worked at Fábrica São Braz, sometimes side by side.

Interviewing former factory workers, women and men alike, it came to my attention that close to 80 per cent lived in houses inherited from their mothers - some even from their grandmothers who had taken possession of these homes at a time when only families working at the factory could inhabit them. In addition to homes, some women also inherited the position of head of household. When I met them in the 1990s, more than half were responsible for households that brought together two or more generations of mothers and daughters whose partners and sexual mates passed through their lives, and who bonded to bring mutual help and support in raising their children and grandchildren.

In Plataforma, this type of household seems to have a long history among the families of the former factory workers interviewed, the ownership of the houses and responsibility for the families passing from mothers to daughters even when husbands and partners were integrated into the domestic groups involved. More importantly, from the information I was able to obtain from the testimonies, these groups could be characterised as matrifocal extended families of more than two generations, constituting what we may identify as informal matrilineages.

Given the importance of women's work in the factory and for the households in question, it would be fair to say that female-headed households, whether matrifocal or not, or with or without the presence of husbands and male 
partners, probably found significant expression throughout the history of the factory in the neighbourhood. As Katia Mattoso (1988) and other historians (Borges 1992; Santos 1993; Ferreira Filho 1994) have shown, in the eighteenth century and throughout the nineteenth, female-headed households were already common in the poor parishes of the city of Salvador. In the case of Plataforma, these households were often formed by desertion of mates, and expanded by children of their daughters' children, who remained at home and sometimes had their partners coming to live with them - thus becoming part of a female-headed extended household.

Several factors seem to have been at play in the formation of these households. The basic one was the financial inability of men to set up a household of their own. Rental facilities were not easy. The company had ceased to build new housing for workers and the existing ones were usually occupied. Land was available for the building of houses, but this was a project to be accomplished over a period of many years, sometimes over a lifetime, and difficult for young couples to start. It was easier to build an extension to an existing house, even a company house. This also figured as a strategy for abiding by company rental policies. Moreover, these households had previously depended on the pooling of financial contributions of all able members - sons and daughters - and could not afford to do without them, especially as the mothers aged and their productivity slowed. At the same time, daughters now had children of their own. If they were to continue working at the factory - as nearly all women like them did and guarantee the company house and the wages to maintain it, they would need their mothers' help in caring for house and children, establishing a trans-generational cycle of mutual help between mothers and daughters. This mutual dependence of mothers and daughters contributed to the formation of matrilocal - and matrifocal - extended households.

While all these arrangements tended to the needs of the households and individuals involved, they were not immune to conflicts. As roles of pai de familia (husband, breadwinner, decisionmaker) and of dona de casa (housewife, homemaker) - complementary roles, in the idealised nuclear family household - became muddled. In a situation of matrilocal extended households, however, there would be more than one individual to fulfil each of these roles, and thus a cause for dispute and conflicts. In Plataforma, mothers remained as heads of their households and the central figure of authority in the family. This strained relations between the conjugal pairs living under their authority and household administration. Their daughters' mates could not fulfil the role of pai de familia expected of them, especially as their unstable jobs and meagre earnings did not enable them to become the sole providers. This contributed to the weakening of conjugal ties and the greater dependence of women on their female kin group.

\section{Plataforma in the twenty-first century: women and families}

As noted, my study in the early 1990s focused on former factory workers, the older population of Plataforma. Most of the homes I visited then were female-headed extended households. However, it was a very small sample, and it centred primarily on workers' memories of family life in Plataforma, when the factory was still in operation. The subsequent larger survey conducted in 2004-5 (Sardenberg and Gonçalves 2005) permitted the identification of some trends regarding household composition and organisation in Plataforma.

We found that households varied considerably in terms of their internal organisation, from singledweller households to those composed by three generations or collateral extended families. Of the total households visited, three generation extended families were still very common in the neighbourhood, constituting 27.4 per cent of the households surveyed. Not surprisingly, we found some very large households, one of them, in particular, headed by a 69 -year-old retired woman was composed of 14 people, including eight children and three grandchildren. Although such large households were exceptions - households in our sample averaged only four to five people close relatives, adult daughters and their families often lived in the same building, or in an extension. This is a common arrangement in poor neighbourhoods in Salvador; as children grow up and begin their own families, the houses 'grow' either up, with new floors being added, or 'out', that is, by extending the house into the backyard. The new additions eventually become independent dwellings; as a popular saying 
affirms: 'Those who marry want a home away from home' - even if, due to economic constraints, 'away' means just a different floor of the house (Sardenberg 1998). Nevertheless, it is important to note that the 'nuclear family-household', composed of a heterosexual couple and their children, the traditional ideal model of the family in Brazil, corresponded to less than one quarter (24.3 per cent) of the households visited.

Our 2004-5 survey confirmed trends that have been observed for Brazil as a whole among the working classes: (1) a significant proportion of female-headed households and their greater vulnerability; (2) the tendency for female household heads to live without partners, and to be older and have less years of formal education than their male counterparts; (3) the sizeable percentages of these women who are retired or receiving pensions; and (4) the equally considerable proportion of these women who have to support unemployed adult children and their spouses as well as grandchildren, with meagre retirement and pension benefits. Within the last three decades, the marked increase in the percentage of households headed by women represents one of the major changes observed in census data as well as in official household surveys (PNAD) in Brazil. For instance, whereas in 1992 these households represented only 19.3 per cent of the total, by 2002 this percentage had risen to 25.5, an increase in the order of 32.1 per cent. This increase was much more pronounced in urban areas, and particularly marked in metropolitan areas in the northeast and north regions, where the proportion of women-headed households was in the order of 35.1 per cent and 35.2 per cent, respectively. Among the metropolitan regions surveyed, the Metropolitan Region of Salvador (RMS) showed the highest proportions: 32.9 per cent (IBGE 2002). Similar studies have also shown that even though increases are to be found in all strata of the urban population, these proportions tend to be even higher among the poor population (DIEESE 2004). Our 2004 survey of Plataforma confirmed this trend. Women-headed households represented 44 per cent of the sample, a figure much higher than the national average of 25.5 per cent (IBGE 2002), even for Salvador (32.9 per cent).

Our survey included a set of questions about division of labour, distribution of financial responsibilities, authority and decision-making within the family-households - such as over who decides about children's education, where to live, who should work within the group, how the earnings of household members should be spent. The results obtained indicated that, whereas financial responsibilities and decision-making were commonly shared almost equally by women and men, even in those households that had a 'male head', domestic tasks - including caring for children, those ill, and the aged - were still treated as women's responsibility. These trends remain. However, women are now complaining about this unfair situation.

\section{Women's empowerment?}

In the last two years (2007-9), we have been conducting a new study in Plataforma as part of the Pathways of Women's Empowerment Research Programme Consortium (RPG). ${ }^{1}$ This study aims to identify and analyse changes in women's lives over the last three generations, and how these changes relate to processes of women's empowerment, looking at educational opportunities, paid employment, political participation, family relations, and expression of sexuality, as well as how changes in each of these aspects of women's lives may bring changes to the others. We went back to our sample of households surveyed in the 2004-5 study, but interviewed only the women, working with a sample of 353 women, ranging from 15 to over 90 years old.

Of these women, 25.8 per cent were identified as household heads without a partner, 36 per cent as spouses, 30 per cent as mothers or daughters, 6.7 per cent as other relatives, and 1.4 as non-kin related members. Among those identified as 'spouses or partners', nearly 66 per cent affirmed that in their homes, they and their husbands/ partners shared the position of being heads. These findings gain greater relevance when we consider that, until 2003, it was still stipulated in the Civil Code (sanctioned in 1916) that the husband/father was the head of the household. ${ }^{2}$ The new Civil Code, sanctioned in 2003, establishes the possibility of shared household leadership. Were the women interviewed simply responding to the change in legislation, or is the Code merely catching up with a change of values and attitudes regarding women's roles in the family?

Our survey also included sets of questions regarding distribution of financial responsibility 
and authority within the households. Our findings indicated that the women interviewed are not only sharing decision-making within their households, particularly with husbands/partners, but also seem to exercise a high degree of 'autonomy' regarding the course of their own lives. Although 15.3 per cent affirmed that they faced resistance on the part of family members (48 per cent of them from husbands and partners) when they decided to find work outside of the home, they did it anyway. In addition, 70 per cent stated that their economic contribution to their families is highly regarded, and 58.9 per cent believe that this contribution has made a difference in the way other household members regard them. Moreover, over half of the respondents (50.4 per cent) believe that their financial contributions to their families have earned them respect within their communities.

A significant proportion - 54.4 per cent - of the respondents stated categorically that they have 'total control' over their lives, while 34.4 per cent affirmed that they had 'considerable control'. For the majority (59.5 per cent) of the interviewed women, marriage is no longer a 'safe port', 98.3 per cent affirming that it is very important for women to have their economic independence. Yet, at the same time that nearly 60 per cent believe that work does not affect a marital relationship or may have a positive effect on it, an equally high proportion (60.1 per cent) are ambivalent insofar as relationships between 'working mothers' and their children are concerned, thus expressing traditional beliefs regarding work and motherhood.

This is consistent with the finding that 96.6 per cent of respondents affirmed they were responsible for performing domestic tasks in their homes, including caring for the children. Although an equally high proportion stated that they share the responsibilities for these tasks with members of their families, the overwhelming majority (90.4 per cent) of them do so with other women, with mothers and daughters in particular. As in the case of the former factory workers, so too the women interviewed more recently are closely bonded to their mothers and daughters for mutual help and support in accomplishing chores, caring for children and the elderly, and finding assistance in moments of need.

\section{Three generations of women and their pathways to empowerment}

Although it is possible to find a significant correlation between age and values in that the younger generations tend to express more 'progressive' values and attitudes regarding women's empowerment, this is not necessarily always the case. 'Dona' Nora constitutes such an example. ${ }^{3}$ At 63 and now retired, she is still very vocal about women's rights and has sought a college education for her daughter and the means for her 14-year-old granddaughter to continue a successful career in international karate competitions. A native of Plataforma, daughter of a canoe boatsman (canoeiro) and a laundry woman (lavadeira), she was raised in a family that included factory workers. She started work young, helping her mother with the voluminous weekly wash. She earned pocket money carrying lunch meals to factory workers from their homes, some of them leaving her leftovers in the pots. 'We were very poor,' she states, 'sometimes I went to bed on an empty stomach.' Dona Nora went to live with her sister to care for her nephews and nieces so that the sister could go to work. This allowed her to witness her sister falling victim to constant acts of domestic violence at the hands of her brotherin-law, a situation that, she claims, made her never want to be married herself. And she never did. But she loved children, she says, and eventually adopted as her own daughter her brother's little girl called Lara, now 36 years old with a daughter of her own with whom Dona Nora lives.

Although she barely completed elementary school, Dona Nora took over a preschool that was founded by an older sister, working as its head for nearly 40 years. She says that in spite of the fact she could barely make ends meet (and could not even buy a house for herself with her meagre earnings), she is proud to have been able to give her daughter a college education, and thus the means for her daughter's empowerment. Nevertheless, unlike her adopted mother, Lara married young and lived in an abusive relationship. When her own daughter 'Dora' was seven, she finally decided to walk out. By then, she had finished college with her mother's support, earned more than her husband, and could not find any reason to remain by his side. She left carrying only her and her daughter's clothes and went back to live at her mother's 
home. At present, she supports her mother, ever since Dona Nora was forced to close the school. Dona Nora and her daughter Lara are both now directing all their energies towards finding sponsors for Dora. 'She is going places,' affirms Dona Nora, 'she will be an Olympic champion.'

\section{Change or continuity?}

In considering changes in women's lives in Plataforma over three generations, it must be stressed that what we found here was not unique to this area - not at present, nor in the past. Despite the absence of systematic studies of working class families in Bahia during the first half of the twentieth century, there is much to indicate that home life among the populace departed in many important ways from the model of the family upheld by the local elites. Contrary to the general principles of this model, for instance, 'illegitimate' births resulting from consensual unions predominated among the working classes of Salvador. Consensual unions were the rule, not the exception among the working classes (Borges 1992). The precariousness of men's jobs made it difficult for them to establish their own households and/or to assume the role of sole providers. Women's contribution to the domestic budget thus became fundamental, granting them greater economic independence, which laid the basis for a more symmetrical relationship (Chalhoub 1986: 137-44). Studies of working class families in Rio de Janeiro, for instance, have shown that women there also contested the authority of the husband/father (Besse 1989), often counting on the support of other women in their families in staging their insubordination (Chalhoub 1986: 150). And, like Plataforma, this situation was more common in those instances in which the young couples, due to economic need, were forced to live with relatives. As such, observed Claudia Fonseca, '... the nuclear units were diluted in these consanguineous groups where strong, long-lasting loyalties contrasted sharply with the precariousness of conjugal ties' (1989: 105, my translation).

Families thus tended to be organised primarily around a mother and her children. 'The mother was the center of this family, though the father might visit, or even live with them in the household' (Borges 1992: 48). ${ }^{4}$ Matricentrality and matrilocal residence were mutually reinforcing, giving rise to matrifocal families and granting women greater relative autonomy and independence than women of the elites. The relatively high frequency at which this seemed to occur among the urban working classes all over Brazil, has engendered speculations concerning the sociocultural dimensions of the observed patterns. Even if, on the one hand, they can be seen as adaptations to socioeconomic conditions (or as 'strategies for survival'), on the other, the regularity in which they seemed to occur suggests that some principles for organisation were in usage. Dain Borges (1992: 48), for example, suggested that these arrangements constituted a distinct model of the family that 'had a long tradition in Brazil' - one that has been especially strongly associated with the AfroBrazilian population (Landes 1947). But he is not clear as to what kind of 'model' it would be: a simply statistical model or a normative model, that is, a recognised, conscientiously upheld set of principles for family-household organisation?

One could say, then, that among the urban working classes, an alternative model of familyhousehold organisation was at play. Yet, this model needed not be 'normative' but instead a modus operandi - or 'habitus' (Bourdieu 1977: 72) - of urban working class families in Brazil. In this case, this 'alternative model' would not imply a rejection on the part of the working classes of family ideals (and the ensuing gender roles) espoused by the elites. As Maria Clementina P. Cunha suggests: 'It is more likely (...) that the same claustrophobic role of the bourgeois woman operated as a parameter of aspiration and of vindication for the popular classes, earmarking a horizon of rights to be conquered' (1989: 144, my translation). Indeed, evidence to that effect is to be found in the discourse and struggles of organised labour. From the late nineteenth century onwards for instance, labour unions in Brazil and other spokesmen for the working classes - whether actually espousing these ideals or instead putting them to work on their behalf - have consistently fought for a family wage, thus claiming the right to constitute stable, conjugal families organised around the gender divide instilled by the bourgeois model. Of course, the thesis that the 'alternative' model of the family put to work among the working classes in Brazil represented in the past a conscious rejection of bourgeois ideals is certainly enticing to socialist-feminists (such as myself). Nevertheless, as Eunice 
Durham poignantly indicates, all available studies and records suggest that, to the frustration of Brazilian radical intellectuals, workers in Brazil have been not only 'extremely attached to the family', but also that:

... (they) express a generalised preference for a sexual division of labour on traditional modes, that is, that which subordinates women to men and tends to restrict female activities to the domestic sphere. At the same time, they also tend to appreciate the traditional virtues of respect and obedience of children towards their parents. (Durham 1980: 201-2, my translation)

From the perspective of women workers, the nonfulfilment of bourgeois gender role ideals has often been translated into the burden of a double day. For these women, in particular, the constitution of matrifocal families, without a stable male provider, has represented '.... a result of poverty, an overload of misery, the impossibility to achieve a minimally decent life instead of a sign of better and freer forms of relations between the sexes' (Durham 1980: 203, my translation).

This seems to have been the case of the women of Plataforma in the past. Among the factory workers I interviewed in the 1990s, even women who were raised in and constituted their own matrilocal extended households and assumed the role of heads as major providers, enjoying a certain independence, were still betrayed in their discourse, which revealed unfulfilled aspirations for the realisation of those ideals. They were not unaware of the contradictions between these ideals and their own life experiences. Indeed, when women asked, 'Why do I need a man that can't even bring me a bag of flour?', they were justifying the 'alternative' paths their lives have taken, precisely in terms of the gender roles intrinsic to bourgeois family ideals. This does not seem to be necessarily the case for the women in our most recent survey. Women in our sample have chosen to end abusive relationships, and some not to marry at all. In the case of Dona Nora and her daughter (and granddaughter), for example, the formation of their female-headed household appears to come as a result of gender resistance and rebellion. Professional, middleclass women in Salvador are exercising agency, both in ending unsatisfying relationships and constituting female-headed (and matrifocal) families (Macêdo 2008), as well as in choosing to remain single and live alone (Tavares 2008).

However, in the case of Plataforma as well as in other poor neighbourhoods of Salvador, processes of women's empowerment regarding family relations are being slowed, if not entirely diverted, by the growth of evangelical churches.

The 2000 Population Census showed Brazil as primarily a Catholic country - 73.8 per cent of the Brazilian population. Yet it is considerably less Catholic than it used to be. Along with Catholicism, Afro-Brazilian religions have lost much ground to Evangelical Christianity, particularly among the poorer and dispossessed, gathering a faithful flock especially among women (Prandi 2003; Bohn 2004). In the survey conducted in Plataforma in 2004, we found that 36.9 per cent of women heads of household, as opposed to 26.1 per cent of male heads, were Evangelical Christians. Among the women interviewed more recently, the figure had risen to close to 40 per cent declared. These religions tend to preach fundamentalist values and be much more conservative than the others, especially insofar as gender relations are concerned: most of them advocate women's obedience to their husbands and a traditional division of labour.

\section{Final considerations}

Taking into consideration the findings from the different studies discussed here, it is possible to see some patterns continuing over time regarding women's empowerment in the sphere of gender relations within the family. The most obvious, of course, is the relevance of women's economic independence to their participation in decisionmaking within the home as well as in terms of autonomy. That is to say, both in the past as well as in the present, economic independence, particularly from partners, seems to have contributed significantly towards women gaining the power to assert control over their own lives, including in ending relationships that fall short of fulfilling the established ideals. To this end, female solidarity, particularly from women kin, has also played a special role: it has propitiated the growth of the exercise of power with to bring about the desired changes in one's lives, as witnessed in the case of Dona Nora's support to her daughter and granddaughter. However, 
despite their relevance, neither economic independence nor female solidarity alone seems to have automatically led to conscious 'gender rebellion' and a break with traditional roles in the family. I contend that this only becomes possible when new values and attitudes in favour of alternative models gain greater expression. Indeed, as indicated in the responses of the women we interviewed more recently, there seems to be a new discourse - a feminist

\section{Notes}

1 See www.pathwaysofempowerment.org

2 This clause was maintained, even though the 'Statute of the Married Woman' passed in 1962 granted married women greater autonomy.

3 In order to preserve the privacy of everyone interviewed in the course of this research, their names and other characteristics that can be used to identify them have been changed.

4 This was illustrated in a report prepared by a famous local paediatrician for the governor of

\section{References}

Besse, S.K. (1989) 'Crimes of Passion: The Campaign Against Wife Killing in Brazil, 1910-1940', Journal of Social History 22.4: 653-66

Bohn, S.R. (2004) 'Evangélicos no Brasil. Perfil Socioeconômico, Afinidades Ideológicas e Determinantes do Comportamento Eleitoral' ['Evangelicals in Brasil. Socio-demographic Profile, Ideological Affinities and Electoral Behaviour Determinants'], Opinião Pública 10.2, Campinas

Borges, D. (1992) The Family in Bahia, Brazil, 1870-1945, Stanford: Stanford University Press

Bourdieu, P. (1977) Outline of a Theory of Practice, Cambridge: Cambridge University Press

Chalhoub, S. (1986) Trabalho, Lar e Botequim: O Cotidiano dos Trabalhadores no Rio de Janeiro da Belle Époque [Work, Home, and Bar: Everyday Life Among Workers in Rio Janeiro during the 'Belle Epoque], São Paulo: Brasiliense

Gunha, M.C.P. (1989) 'Loucura, Gênero Feminino: as Mulheres do Juquery na São Pauldo do Início do Século XX' ['Madness, Female Gender: Women in Juquery in 20th Century São Paulo'], Revista Brasileira de História 9.18, São Paulo

DIEESE (2004) 'A Mulher Chefe de Domicílio e a Inserção Feminina no Mercado de Trabalho' ['Women Heads of Households and Female discourse - about women's roles and women's rights finding expression among working class women in Brazil. This, we may say, is contributing to the growth of self-esteem and self-confidence of the power within - among these women as well, of which Dora's Olympic aspirations are a good example. But only time will tell if this new discourse will hold its ground against the rise of religious fundamentalism brought by Evangelical Christianity in the neighbourhood.

the State of Bahia in 1924. The report indicated that among 3,091 youngsters registered with the agencies assisting poor children run by the Bureau of Child Hygiene of the City of Salvador, 54.28 per cent were illegitimate. In addition, 31.28 per cent had fathers who were either absent or unemployed while the overwhelming majority - 94.17 per cent - had working mothers (Ferreira Filho 1994: 23-34).

Insertion in the Labor Market'], Boletim DIEESE, Salvador: Departamento Intersindical de Estatística e Estudos Socioeconômicos

Durham, E. (1980) 'Família Operária: Consciência e Ideologia' ['Working Class Families: Consciousness and Ideology'], Revista Dados 23.2: 201-14

Ferreira Filho, A.H. (1994) Salvador das Mulheres. Condição Feminina e Cotidiano Popular na Belle Epoque Imperfeita [Salvador of the Women: Feminine Condition and Everyday Life Among the Populace in the Imperfect Belle Epoque], Salvador: Mestrado de História/Universidade Federal da Bahia

Fonseca, C. (1989) 'Pais e Filhos na Família Popular' ['Parents and Children in Families Among the Populace'], in M.A. D'Incao (ed.), Amor e Família no Brasil [Love and Family in Brazil], São Paulo: Contexto

Hall, J.D.; Leloudis, J.; Rodgers Korstad, R.; Murphy, M.; Jones, L.A. and Daly, C.B. (1987) Like a Family: The Making of a Southern Cotton Mill World, New York: W.W. Norton \& Company

IBGE (2002) Pesquisa Nacional por Amostra de Domicílio - PNAD [National Household Survey], Brasil: Instituto Brasileiro de Geografia e Estatística

Kabeer, N. (1999) 'Resources, Agency, Achievements: Reflections on the 
Measurement of Women's Empowerment', Development and Change 30.3: 435-64

Landes, R. (1947) The City of Women, New York: The MacMillan Company

Macêdo, M. (2008) Na Trama das

Interseccionalidades: Mulheres Chefes de Família em Salvador [In the Weave of the Intersectionalities: Women Heads of Households in Salvador], Tese de Doutorado, Programa de Pós-Graduação em Ciências Sociais - Faculdade de Filosofia e Ciências Humanas, Salvador: Universidade Federal da Bahia

Mattoso, K. de Q. (1988) Família e Sociedade na Bahia do Século XIX [Family and Society in 20th Century Bahia], São Paulo: Corrupio

Parr, J. (1990) The Gender of Breadwinners. Women, Men, and Change in Two Industrial Towns, 1880-1950, Toronto: University of Toronto Press

Prandi, R. (2003) 'As Religiões Afro-Brasileiras e Seus Seguidores' ['Afro Brazilian Religions and Their Followers'], Civitas, Revista de Ciências Sociais 3.1: 15-34

Santos, M.A. da S. (1993) 'Habitação em Salvador: Fatos e Mitos' ['Housing in Salvador: Facts and Myths'], in S. Bresciani (ed.), Imagens da Cidade. Séculos XIX e XX [Images of the City: 19th and 20th Centuries], São Paulo: Marco Zero

Sardenberg, C.M.B. (1998) 'Mães e Filhas: Etapas do Ciclo de Vida, Trabalho e Família entre o Antigo Operariado Baiano' ['Mother and Daughters: Phases of the Life Cycle, Work, and the Family Among the Bahian Working Classes in the Past'], Caderno CRH 29: 21-48

Sardenberg, C.M.B. (1997a) In the Backyard of the Factory: Gender, Class, Power, and Community in
Bahia, Brazil, Ann Arbour, Michigan: UMI Dissertation Services

Sardenberg, G.M.B. (1997b) 'O Bloco do Bacalhau: Protesto Ritualizado de Operárias na Bahia' ['The "Bloco do Bacalhau": Ritualized Protest Among Women Workers in Bahia'], in A.A. Costa and I. Alves (eds), Ritos, Mitos e Fatos: Mulher e Gênero na Bahia [Rites, Myths, and Facts: Women and Gender in Bahia], Salvador: Núcleo de Estudos Interdisciplinares Sobre a Mulher/ Universidade Federal da Bahia

Sardenberg, G.M.B. and Gonçalves, T. (2005) Enabling Urban Poor Livelihoods Policy Making: Understanding the Role of Energy Services, Brazil Country Report, Salvador, Bahia: Winrock International

Sardenberg, C.M.B., Capibaribe, F. and Souza C. (2008) 'Tempos de Mudança, Vidas em Mutação: O Empoderamento de Mulheres na Bahia Através das Gerações' ['Changing Times, Changing Lives: Women's Empowerment Through the Generations in Bahia'], Trabalho Apresentado no Fazendo Gênero 8, Florianópolis: Instituto de Estudos de GêneroUFRGS

Tavares, M. (2008) Os Novos Tempos e Vivências da Solteirice em Compasso de Gênero: Ser Solteira e Ser Solteiro em Aracaju e Salvador [The New Times and Livelihoods of Being Single in a Gender Compass: Being a Single Woman and Being a Single Man in Aracaju and Salvador], Tese de Doutorado, Programa de Pós-Graduação em Ciências Sociais - Faculdade de Filosofia e Ciências Humanas, Salvador: Universidade Federal da Bahia 